\title{
Cattle and their colours: A synchronic investigation of cattle colour terminology in Northern Sotho ${ }^{1}$
}

\author{
Elsabé Taljard \\ Department of African Languages, University of Pretoria \\ elsabe.taljard@up.ac.za
}

In Northern Sotho, a separate colour lexicon is distinguished, containing terms which are believed to be used exclusively as colour terms to describe not only the colours, but also the colour patterning found among domestic animals, particularly cattle. According to current literature, the use of these terms is restricted to the description of cattle and/or other domestic animals. This study, which is corpus-based, investigates the metaphorical extension of these terms which widens their descriptive scope to include objects other than cattle. It is furthermore argued that these terms have unique grammatical features, found nowhere else in the grammatical system of Northern Sotho. Lastly, the metaphoric link between these colour and colour-pattern terms and similar sounding words designating other animals, birds or everyday objects is investigated. It is concluded that this particular colour lexicon is of an ambivalent nature: on the one hand it is an indigenous knowledge system which is clearly in decline, mostly due to non-linguistic factors, but simultaneously, its ability to be extended to the description of other objects points towards a certain measure of vitality.

\section{Introduction}

It is generally accepted by linguists and anthropologists alike, that within the Northern Sotho lexicon a closed sub-lexicon exists, containing terms which are believed to be exclusively used as colour terms to describe not only the colours, but also the colour patterning found among domestic animals, particularly cattle. It is assumed by scholars that the use of these terms is restricted to the description of cattle and/or other domestic animals. No consideration has hitherto been given of the possibility that these terms could also be used to describe objects other than domestic animals, suggesting some kind of metaphorical extension of the use of these terms. Secondly, 
within the realm of Northern Sotho grammar, very little attention has been paid to a thorough grammatical description of so-called colour terms. Although these words are used as adjectives, they are seldom, if ever, mentioned when this word category is formally discussed. It would seem as if grammarians regard them as a special category, based on their presumed restricted referential properties and low frequency of use. The unique properties of these terms with regard to morphological derivation are not prominent in current grammatical descriptions, neither is any reference made to the ability of at least some of these terms to appear as nominals. Lastly, no mention is made of the fact that some of these terms have a relationship with similar sounding words designating other animals, birds or objects. These observations clearly warrant a revisit of the so-called cattle colour terms, addressing the issues mentioned above. The availability of a large scale electronic data corpus for Northern Sotho, the University of Pretoria Sepedi Corpus, (henceforth PSC) offers the possibility of insights not previously possible. ${ }^{2}$

\section{Northern Sotho colour lexicons}

With reference to Northern Sotho colour terminology in general, it would seem that grammarians, albeit implicitly, distinguish between two separate colour lexicons, viz. ordinary colour terms, henceforth called Lexicon A and colour terms reserved for reference to domestic animals, specifically cattle (Lexicon B). Although the latter could be regarded as a closed system, Poland-Oosthuizen (1996: 39) points out that although certain terms are a fixed part of the tradition, the fluid and individual way in which they can be combined to form unique descriptions of individual animals represents a dynamic aspect of the system. Lexicon A is clearly an open system, due to the possibility of increasing the lexicon by means of loan words taken from languages such as English and Afrikaans. This lexicon can be divided into what Berlin and Kay (1969) call basic colour terms and non-basic colour terms, although this distinction is not of particular importance for the current discussion. Compare:

\section{LEXICON A}

- Basic colour terms: -hubedu 'red', -so 'black', -šweu 'white', -tala 'green'

- Non-basic colour terms: 
- Indigenous terms derived from the names of other objects: modipa 'orange' (< modipa 'reddish-brown kind of millet') serolane 'yellow' (< serolane 'yellow fruit of the bitter apple')

○ Terms not regarded as basic in terms of Berlin and Kay's (1969) hypothesis:

-sehla 'grey, yellowish, tawny', -tso(o)thwa 'brownish', -sotho 'brown'

○ Loan words:

pinki 'pink', phepholelphephurelpurapura 'purple', thekoise 'turquois', bolowu 'blue', etc.

Giving an account of Lexicon B-which is the focus of this article-is rather less straightforward. Linguists and anthropologists seem to agree on the content of this lexicon; however, as to the semantic content of the individual terms, little or no consensus exists. For the identification of the members of this lexicon, reference was mainly made to the work by Louw (1957), Mönnig (1978) and Nokaneng and Louwrens (1988). Two standard Northern Sotho dictionaries, those of Ziervogel and Mokgokong (1975) and Kriel and Van Wyk (1989) were used to glean further information on the semantic content of these terms. Compare the following table for an inventory of these terms and a paraphrase of the semantic content of each as found in the various sources: 
Table 1: Lexicon B colour and colour pattern terms

\begin{tabular}{|c|c|c|c|c|c|}
\hline Term & Louw (1957) & Mönnig (1978) & $\begin{array}{ll}\text { Nokaneng } & \& \\
\text { Louwrens }(1988)^{3} & \end{array}$ & $\begin{array}{ll}\text { Ziervogel } & \& \\
\text { Mokgokong (1975) } & \end{array}$ & $\begin{array}{l}\text { Kriel and Van Wyk } \\
(1989)^{4}\end{array}$ \\
\hline -hlaba & yellowish red & red with brown spots & $\begin{array}{l}\text { red all over mixed with } \\
\text { black }\end{array}$ & $\begin{array}{l}\text { fawn with brown on } \\
\text { neck and back }\end{array}$ & light brown \\
\hline -kebja & light grey & white with red spots & $\begin{array}{l}\text { grey mixed with } \\
\text { indistinct black }\end{array}$ & $\begin{array}{l}\text { red or brown with tiny } \\
\text { red spots }\end{array}$ & $\begin{array}{l}\text { red or brown with white } \\
\text { spots }\end{array}$ \\
\hline $\begin{array}{l}\text {-kgoopa } \\
\text { /-kgwapa }\end{array}$ & red and white backed & $\begin{array}{l}\text { black with some white } \\
\text { under neck }\end{array}$ & $\begin{array}{l}\text { black with white under } \\
\text { the neck }\end{array}$ & $\begin{array}{l}\text { black with grey under } \\
\text { neck }\end{array}$ & $\begin{array}{l}\text { black with grey under } \\
\text { neck }\end{array}$ \\
\hline$-k g w a(a) d i$ & $\begin{array}{l}\text { spotted, black or red } \\
\text { with mixture of white }\end{array}$ & black with white spots & $\begin{array}{l}\text { black with white spots } \\
\text { on back }\end{array}$ & black with white back & black with white back \\
\hline -khulong & red & red & - & red & red \\
\hline -nala & $\begin{array}{l}\text { red and white, distinctly } \\
\text { marked }\end{array}$ & $\begin{array}{l}\text { red with a few white } \\
\text { marks }\end{array}$ & red with white belly & $\begin{array}{l}\text { brown or red, spotted on } \\
\text { belly }\end{array}$ & red and white \\
\hline -phaswa & black and white & $\begin{array}{l}\text { red with small white } \\
\text { marks }\end{array}$ & black with white belly & $\begin{array}{l}\text { black with white spots } \\
\text { on flanks }\end{array}$ & black and white \\
\hline $\begin{array}{l}\text {-phefadu } \\
\text { /-phifadu } \\
\text { /-phefadi }\end{array}$ & - & - & very dark red & brown (cf. -SOTHO) & brown \\
\hline $\begin{array}{l}\text {-phitshwa } \\
\text { /-phiswa }\end{array}$ & brown & - & very dark red & dark brown & dark brown \\
\hline $\begin{array}{l}\text {-pududu / } \\
\text {-putswa }\end{array}$ & dark grey & white with black spots & - & grey-coloured & grey \\
\hline
\end{tabular}




\begin{tabular}{|c|c|c|c|c|c|}
\hline $\begin{array}{l}\text {-sega } \\
\text { /-tsheega }\end{array}$ & stripped [sic] or belted & $\begin{array}{l}\text { red with white mark on } \\
\text { side }\end{array}$ & red with a white belt & red and white & red and white \\
\hline -sehla & yellow & - & - & yellow, fawn, tawny & yellow, dun, grey \\
\hline -šweu & white & white & - & white & white \\
\hline- so & black & black & - & black & black \\
\hline -thamaga & $\begin{array}{l}\text { red and white, not } \\
\text { distinctly marked }\end{array}$ & $\begin{array}{l}\text { red with white spots on } \\
\text { back }\end{array}$ & $\begin{array}{l}\text { red with whitish sides } \\
\text { and white back }\end{array}$ & red with white back & red and white \\
\hline $\begin{array}{l}\text {-tho(o)ko } \\
\text { /-thokwa }\end{array}$ & dark brown or fawn & $\begin{array}{l}\text { mixed red, white and } \\
\text { black }\end{array}$ & - & greyish brown & greyish brown \\
\hline $\begin{array}{l}\text {-thomo } \\
\text { /-romo }\end{array}$ & ash like & $\begin{array}{l}\text { black with a few white } \\
\text { marks }\end{array}$ & $\begin{array}{l}\text { black with white on the } \\
\text { body }\end{array}$ & black and white spotted & black and white \\
\hline $\begin{array}{l}\text {-tshumu } \\
\text { /-tšhumu }\end{array}$ & $\begin{array}{l}\text { red and white faced, or } \\
\text { black and white faced }\end{array}$ & $\begin{array}{l}\text { red with white mark on } \\
\text { face }\end{array}$ & $\begin{array}{l}\text { red or black with white } \\
\text { face }\end{array}$ & $\begin{array}{l}\text { white-faced, red or } \\
\text { black with spots and a } \\
\text { blaze }\end{array}$ & white-faced \\
\hline $\begin{array}{l}\text {-tšipu } \\
\text { /-tšhipu }\end{array}$ & - & red with white markings & - & $\begin{array}{l}\text { black with tiny white } \\
\text { dots (of sheep only) }\end{array}$ & - \\
\hline -tsokotla & - & - & $\begin{array}{l}\text { black with a reddish } \\
\text { sheen }\end{array}$ & roan & dapple, roan \\
\hline
\end{tabular}


The divergent views of scholars with regard to the semantic content of these terms are immediately evident. This is probably due to the fact that this system is in a process of decline because of socio-economic change caused by increasing urbanisation of Northern Sotho speakers and that they are increasingly involved in other sectors of the economy. Poland-Oosthuizen (1996: 41) states the following with regard to the cattle terminology of Zulu:

...cattle terminology is a 'text' of ancient provenance which is known to fewer and fewer people. As the environment changes and the cattle-culture declines and as the birds and the beasts which once so abundantly shared the cattle's pasture diminish, so a full understanding of the names, their metaphorical associations and the poetry in their form, is irretrievably lost.

There is also a decline in the social value of cattle in that one of the main functions of cattle, i.e. to be utilised as magadi 'marriage goods', has been taken over by monetary compensation. Furthermore, minute descriptions of the physical attributes of cattle were traditionally a means of identification and of confirmation of ownership in the case of disputes. Modern technology has made this means of identification to a large extent redundant. A further possible explanation for the fluidity of the system is the fact that these terms have for many decades formed part of an oral tradition, with the inherent flexibility allowed by oral transfer of (indigenous) knowledge.

Also evident from the inventory given above is the orthographic variation in these forms. For some unexplained reason, it would seem that these forms have slipped through the standardisation net, possibly because of their perceived archaic nature and low frequency of use.

Clarity regarding the semantic content of these terms can only be obtained by means of extensive field work, similar to the work done by Poland-Oosthuizen (1996) for Zulu, involving traditional herdsmen as informants. This would, however, constitute a separate study. Questions that need to be addressed by such an investigation include, but are not limited to, the following:

- Seeing that one term may describe a range of patterns (cf. -kgwadi and -nala), to what extent are the terms designating colour patterns exact descriptions, or do they represent ideal distributions of which the term is an approximation? 
- Can these terms be combined in a dynamic way to form unique descriptions aimed at describing an individual animal? If yes, do these combinations follow a particular cognitive pattern, e.g. reference to dark/black being dominant over reference to light/white?

- Are any additional, as yet unrecorded terms, to be found for the description of cattle colours and colour patterns?

\section{Grammatical features of Lexicon B terms}

In both of the standard Northern Sotho dictionaries in which part of speech is indicated for lemma signs, i.e. Ziervogel and Mokgokong (1975) and Kriel and Van Wyk (1989), the part of speech of Lexicon B forms is consistently indicated as adjective. This is confirmed by information gleaned from the corpus. Compare a random sample of examples culled from the PSC:

(1a) Ke motho yo mohlaba ka mmala; yo motelele ka leemo, wa ditsebe tša go tlogela hlogo.

'He is a person with a light (brown) complexion, of tall stature with large, prominent ears.'

(1b) Ke pudi ya mmala wo mothomo.

'It is a black and white coloured goat.'

(1c) Kua thabeng ya Bokone matlapeng a mapududu...

'Over there in the Bokone mountains, among the grey rocks...'

There are, however, a number of features that are exclusive to Lexicon B colour terms. The first is the indication of feminine gender by means of unique affixal strategies. Two strategies are used in this regard; the first is the use of the diminutive suffix -(a)na; the second, the utilisation of a prefix $n a-$, which is added to the adjective stem. Instances are also found where both prefix and suffix are used simultaneously. Compare the following corpus examples:

(2a) Kgomo ye khulong ke ya mmala wo mohubedu mola ya tshadi yona e bitšwa kgomo ye khulwana. 
'A reddish brown bull/ox is of a red colour, whereas a female animal is called a red cow.'

(2b) Botša Baisiraele o re ba ntšhe kgomo (y)e nakhulong, e se nago bosodi.

'Tell the people of Israel to bring a red cow, which does not have any defect.'

(2c) Ka tšatši leo a kgetha diphokwana tše mebala le tše tshega, le dipudi ka moka tše nakgwana le ť̌e nasegana.

'On that day he selected multi-coloured and red and white belted billy goats and all the spotted and red and white belted she-goats.'

The affixal strategies used to indicate feminine gender represents a feature which is unique to cattle colour terminology. Generally, feminine gender is expressed by means of specific lexical items, e.g. mosetsana 'girl', mosadi 'woman', etc. or by means of the rather limited application of the suffix -gadi, e.g. taugadi 'lioness', mohlologadi 'widow', etc. Alternatively, femininity with regard to animals can be expressed by means of a possessive construction, cf. mpša ya tshadi 'bitch, female dog', or by using -tshadi as an adjective stem, cf. tlou ye tshadi 'elephant cow'. The suffix -(a)na (compare 2(c)) is probably related to the diminutive suffix, but its utilisation to indicate feminine gender is restricted to adjectival stems indicating colours or colour patterns in cattle and other livestock. Elsewhere in the grammar the default relation is usually between feminine gender and large size, both being expressed by means of the -gadi suffix - a phenomenon which is not restricted to Northern Sotho, but which also appears in the other Sotho languages as well as in the Nguni languages (Güldemann, 1999: 75).

Apart from its utilisation to indicate feminine gender, the suffix - $(a)$ na is also used to express the notion of being e.g. somewhat red, reddish '-khulwana', somewhat light-skinned '-hlabana', etc. The context in which such examples occur usually enables one to disambiguate the meaning imparted by the suffix, cf.

(3) (Monna wa mathomo) e be e le yo mohlabana ka mmala mme sefahlego sa gagwe se phela se tletše lethabo.

'(The first man) was fairly light-skinned and his face was always full of happiness.' 
The origin of the prefix $n a$ - is rather more problematic, and at this stage nothing more than a tentative hypothesis can be put forward. Initially, it seemed that distribution of this prefix was restricted to Lexicon B colour terms, in which case it is used to express feminine gender. However, two nouns displaying what appears to be the same prefix are found in Northern Sotho, i.e. namagadi, which according to Kriel and Van Wyk (1989) is a noun belonging to class 9, expressing the meaning of 'female animal, cow, ewe, mare'. In the online Northern Sotho-English dictionary, Pukuntšu ya Sesotho sa Leboa-English, the meaning is given as 'female' and as 'cow held in special esteem, wonderful old cow!' The second example is nameru 'pregnant cow'. In Tswana, a remnant of what seems to be the productive use of this prefix is found. According to Dr Jurie le Roux (e-mail, 12 August 2014), the noun mokgantsutswane 'lizard' is classified as belonging to class 3-this would represent its primary classification, cf. Maho (1999: 88). The class 3 prefix mo- can, however, be substituted by na-, thus nakgantsutswane, in which case the prefix would serve to indicate the praiseworthiness of the lizard. A second example cited by Le Roux is nammutla, which consists of the prefix na- affixed to the class 3 noun mmutla 'hare', while retaining the original class 3 prefix $* m o-$. This example is found in a praise poem in which the athletic ability of the addressee is praised by comparing him/her to a hare. The notion that the prefix $n a$ - in some way expresses high esteem for the objects referred to ties in well with the explanation of meaning given above for the term namagadi. The premise at this stage is that a noun class housing nouns with the semantic feature 'feminine' and/or 'highly esteemed' could have formed part of the original noun class system in Bantu. The prefix would have been productive in the sense that nouns could be transferred, so to speak, from their primary classes to a special class associated with the aforementioned features by prefixing $n a$ - either to the noun with retention of its primary prefix, or by prefixing it to the noun stem, in which case the primary prefix will have been deleted. Since in adjective constructions the adjective stem carries the prefix of the noun, the prefix $n a$-could possibly be a remnant of a now defunct noun class prefix. However, such a premise needs further in-depth investigation and would entail a detailed comparative study involving a sizable number of other Bantu languages - an endeavour which falls outside the ambit of the current study.

A second feature of Lexicon B terms is their proclivity to be used as nouns, i.e. without the demonstrative (resp. qualificative or adjectival particle/prefix) which 
usually forms part of the adjective construction. The term -tshehlana serves as a case in point. A corpus search resulted in 144 hits, but of these, only 30 (20.8\%) appear in the full adjective construction; the rest appear as nouns, functioning inter alia as subjects and objects of sentences. Compare 4 (a) and (b) in this regard:

...nonyana ye nnyane ye tshehlana ya mebalana ye meswana mmeleng

'... a small, tawny bird with some black colours on the body'

(4b) E šetše e le mantšiboa ge Ranotoane a laela tshehlana ya gagwe.

'It was already evening when Ranotoane said goodbye to his girlfriend.'

Although such a phenomenon is not completely unknown with regard to Lexicon A colour terms, the incidence is much lower. A corpus search for the form -khubedu, for example, resulted in 119 hits, of which only one represented an example in which -khubedu is used as a noun. Compare:

... a palelwa ke go itsoša, ebile o tsuruma khubedu dimpeng.

'...he could not revive himself, and was gushing blood from his stomach.'

It would seem that Lexicon B terms have a greater tendency to be lexicalised as nouns, sometimes with a new meaning, but in some cases these terms are simply used as nominalisations of the corresponding adjectival stem. In this particular case, it could be argued that there has been lexicalisation of the adjective stem into a new meaning, as is evident from the translation.

\section{Lexicons $A$ and $B$ as fluid categories}

An initial perusal of random examples harvested from the PSC revealed that contrary to the generally accepted view put forward in grammars and dictionaries, terms belonging to Lexicon $\mathrm{B}$ are not restricted to the description of cattle and/or other domestic animals. In view of the relatively restricted lexicon of ordinary colour terms in Northern Sotho, this observation does not seem that unusual, but the immediate implication is that the two lexicons should not be regarded as absolutely distinct categories, but that there is some degree of mobility for the terms categorised as belonging to either of the two lexicons. It would seem that the semantic implications of Lexicon B terms can be metaphorically extended to include descriptions of other 
objects as well. Table 2 below tabulates the results of an analysis of the nature of antecedents qualified by means of Lexicon B items. The term antecedent is used in this context not to refer to the grammatical antecedent, but rather to the object which is metonymically referred to by the description. Should the term -pududu 'grey' for example be used to qualify hlogo 'head', i.e. hlogo ye pududu, where the 'grey head' is used to refer metonymically to a grey-haired person, the antecedent is taken to refer to a human. Note that all derivations of the Lexicon B terms were included in the search; a canonical form was selected to represent all derivations in the table. Shaded blocks indicate colours, whereas unshaded ones mark colour patterns.

Table 2: Nature of antecedents described by Lexicon B terms

\begin{tabular}{|c|c|c|c|c|c|}
\hline \multirow{2}{*}{$\begin{array}{c}\text { LEXICON B } \\
\text { TERM }\end{array}$} & \multicolumn{5}{|c|}{ NATURE OF ANTECEDENT } \\
\hline & Cattle & $\begin{array}{l}\text { Other domestic } \\
\text { animal }\end{array}$ & Human & Inanimate & Total no of hits \\
\hline$-h l a b a$ & 15 & & 14 & & 19 \\
\hline -kebja & 4 & & & & 4 \\
\hline$-k g w a d i$ & 15 & 2 & & 1 & 18 \\
\hline$-k g w a p a$ & 4 & & & & 4 \\
\hline -khulong & 2 & 32 & 21 & 12 & 67 \\
\hline -nala & 11 & 3 & & 2 & 16 \\
\hline -phaswa & 10 & 10 & & & 20 \\
\hline -phifadu & & 5 & & & 5 \\
\hline -phitswa & 3 & & & 1 & 4 \\
\hline -pududu & 6 & 3 & 19 & 10 & 38 \\
\hline- seega & 9 & 4 & & & 13 \\
\hline -sehla & & 8 & 11 & 22 & 41 \\
\hline -thamaga & 2 & 7 & & 2 & 11 \\
\hline \multicolumn{6}{|l|}{-thooko } \\
\hline -thomo & 4 & 12 & & 1 & 17 \\
\hline -tšhumu & 4 & 4 & & & 8 \\
\hline \multicolumn{6}{|l|}{-tšipu } \\
\hline -tsokotla & 1 & 1 & & & 2 \\
\hline
\end{tabular}


The corpus-based investigation reveals that only two Lexicon B terms are exclusively reserved for the description of cattle, i.e. -kebja and -kgwapa. No examples were found in the corpus of cattle being described by means of -phifadu, despite it being listed as a cattle colour term in three of the sources cited in Table 1. The consolidated results of the investigation as to the nature of antecedents qualified by Lexicon $\mathrm{B}$ terms are given in Figure 1:

Figure 1: Consolidated results: nature of antecedents of colour and colour pattern terms

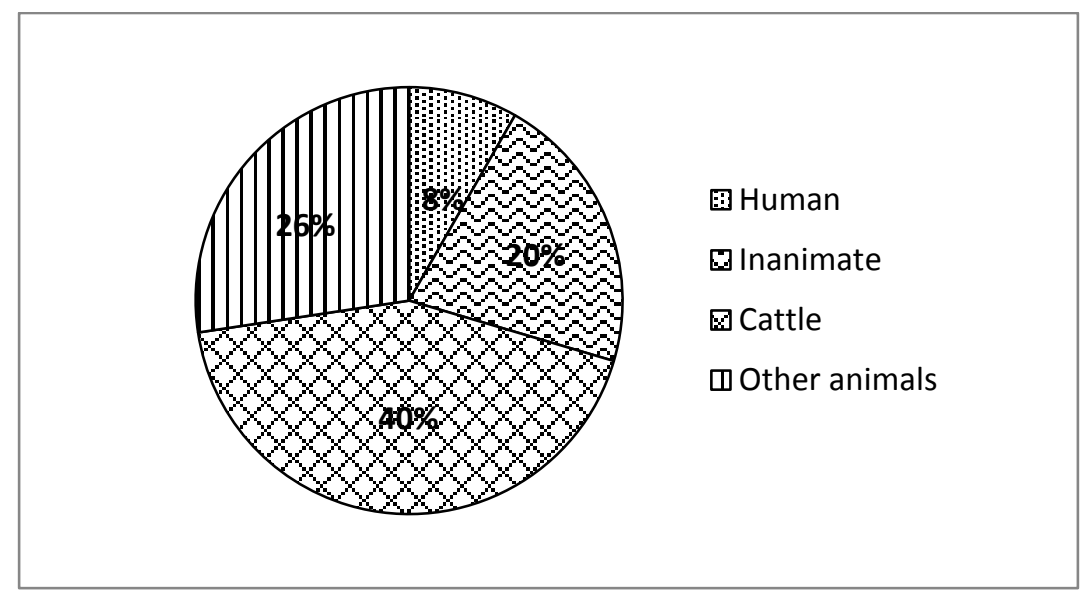

Of particular interest are examples where Lexicon B terms are metaphorically extended to include humans and inanimates in their descriptive valence. An analysis of some of the most prominent examples will illustrate that the metaphoric extension is in most cases the result of an obvious visual similarity between the colour or colour pattern designated by the Lexicon B term and the physical appearance of the object being described. Compare the following examples containing the term -hulwana 'reddish':

(6a) Dilamune di šetše di budule di hubetše, motho a be a bone eka di oketša botse bja ngwako woo wa maboto a mahulwana.

'The oranges were already ripe and red, and it was as if they enhanced the beauty of the house with the reddish-brown walls.'

(6b) O be a no kgetha mahlare a matala le a mahulwana fela, ke go re, matlakala a masome le masomepedi a diranta fela. 
'He selected only green and reddish-brown notes (lit. leaves), that is ten and twenty rand notes.'

In (6a), confirmation of the reddish hue of the walls is found in the comparison with the colour of the oranges growing nearby, thus establishing a conceptual link between the colour of a reddish-brown cow and the colour of the walls. In (6b) the meaning of the stem -hulwana is metaphorically extended to include also the reddish-brown colour of a twenty rand note. Other examples which include the metaphoric extension of the term -khulong/-khulwana include the description of polastiki 'plastic', tamati 'tomato', baki 'jacket', kgabo 'flame', mabele 'millet', lepanta 'belt' and madi 'blood'.

In (7), the visual link between the colour term and its metaphoric extension is not so much the colour, but rather the colour pattern. Compare for example:

...megato ya Sehlodimare e ipontšhitše nakong ya go apoleng ga tatagwe kobo ye thamaga.

'Sehlodimare's charms showed themselves after his father had relinquished the chieftainship. (lit. after his father had taken off the leopard skin)'

(7b) (Lepogo)...Ye thamaga e be e eya kua le kua, e fela e okamela tlase ga leswika

'(The cheetah)...The spotted one went this side and that side, looking under the rock'

When looking at the glosses provided for the term -thamaga in Table 1, the colours which are involved are clearly specified as being red and white, although some difference of opinion exists with regard to the configuration of these colours. The colours red and white are admittedly difficult to associate with the coloration of a cheetah or a leopard, but what is important for the metaphoric extension in these cases is the spotted pattern, rather than the colours.

In some cases, what started out as metaphoric extensions has already been lexicalised into new meanings, with only a tenuous link between the colour term as the source item and the newly coined descriptive term. One such case is the stem -hlaba, which expresses the notion of 'fair skinned' or 'light (brown) of skin', mostly used with reference to humans, which represents the newly lexicalised 
meaning which is diachronically linked to the Lexicon B colour term. Compare the following example:

Ka sebaka Bammala ba bitšwa Batho ba Bahlaba.

'Sometimes Coloured people are called 'Light-skinned people'.'

A second, similar example is the stem -sehla:

(9) Mahlare o be a na le barwedi ba bane, ba basehla, ba mmala wa makhura a lefehlo.

'Mahlare had four daughters, fair-skinned ones, the colour of the fat on a wooden ladle.'

It is furthermore interesting to note that no examples were found in the corpus where the term -sehla 'yellowish, tawny' is actually used to describe cattle. It is therefore not clear on what basis this term is regarded as belonging to Lexicon $\mathrm{B}$, cf. Table 1. However, the fact that no such examples are found in the corpus should not be regarded as final and irrefutable proof that the stem -sehla cannot be used to qualify antecedents referring to cattle.

Going back to Lexicon A, our cognitive knowledge of cattle allows for the assumption that four terms belonging to this lexicon should be utilisable to qualify antecedents referring to cattle, i.e. -so 'black', -šweu 'white', -sehla 'yellowish, tawny' and -sotho/-tso(o)tho/-tso(o)thwa 'brown'. The terms for black and white are indeed used in this manner, and can also be derived for indication of feminine gender, cf.

O be a lefša ka kgomo ye swana.

'He was paid with a black cow.'

Reference has already been made to the fact that no corpus examples were found in which -sehla 'yellowish, tawny' is used to describe the colour of cattle. This is also true with regard to -sotho/-tso(o)tho/-tso(o)thwa 'brown'-no example of this stem being used with reference to cattle was revealed by the corpus search. However, the same disclaimer with regard to the final authority of the corpus is valid here. It is not 
clear whether any significance should be attached to the fact that the only two Lexicon A terms that can be used as cattle colour terms, are 'black' and 'white', which are categorised as basic colour terms by Berlin and Kay (1969), or whether this is simply a coincidence.

The corpus search revealed a single example in which the stem -hubedu 'red' (another basic colour term) is used with reference to a cow; however, when the context in which it occurs is studied, it appears that the term is only utilised to semantically 'unpack' the meaning of a Lexicon B term:

Kgomo ye khubedu ya mmala wo mošweu ka mokolong ke ye tsheega.

'A red-coloured beast with white on the back is called tsheega.'

From the above it is clear that as a result of metaphoric extension, Lexicon B terms are not restricted to the description of antecedents referring to cattle, as substantiated by examples from the PSC. This process of metaphoric extension is of a synchronic and possibly somewhat idiosyncratic nature. It can furthermore be based on a visual and/or conceptual similarity between the appearance of the object being described and either the colour or the colour pattern expressed by the Lexicon B term.

\section{Relationship between cattle colour and colour patterns, and other objects}

One of the prominent issues discussed in Poland-Oosthuizen's (1996) study is the relationship between cattle colour and colour pattern terminology and other objects found in the environment in which the cattle and their herders find themselves. In her discussion she focuses on the visible similarities between colours and colour patterns where the physical appearance of a plant, bird or other (mainly natural) object echoes the colour or colour pattern of a cow. Naming cattle after natural phenomena is a wide-spread practice in Africa-Evans-Pritchard (1940: 41) refers to cattle naming practices amongst the Nuer of Sudan, establishing associations between wild creatures and cattle. According to Poland-Oosthuizen (1996: 343), 'in the consciousness of the people who owned the indigenous cattle of Africa, there were - and are - similarities in the perception of cattle and naming practice which associates these cattle with phenomena found in the environment in which they live'. With regard to the diachronic nature of the relationship between the colour term and the designation of a natural phenomenon, Coote (2012:257) states that 
those cattle colour terms...which are clearly related linguistically to natural phenomena, are in no doubt derived from the term for the phenomenon and not vice versa. Presumably the Dinka called the leopard kuac before they called the spotted ox makuac.

However, this link between the name of a colour or colour pattern should not be seen only as an analogy, based on physical resemblance, but as a cognitive phenomenon which reflects a metaphoric link between different objects. In contrast to the synchronic and dynamic metaphoric extension of cattle colour terms to other objects described above, naming of cattle after natural phenomena seems a much more diachronically complete process. Furthermore, although these metaphorical names have their origin in analogy, they transcend the purely analogous in that the colour term becomes an independent entity, embodied in a colour or colour pattern which exists separately from the referent.

The metaphoric relationship between the appearance of a cow/ox and other natural phenomena such as birds, plants and other animals is reflected in a linguistic link in the form of either morphological and/or phonological correspondence between the colour term and the name of the object or animal. As Poland-Oosthuizen (1996: 417) points out, apart from men, birds are most constantly in the presence of cattle, and throughout Africa, their names and the names of cattle colour patterns are linked. This is also true with regard to Northern Sotho. The stems -khulong 'red', -kgwadi 'black and white' and -thomo 'black with white markings' and their variants are a case in point.

In a list of Northern Sotho bird names published by Louwrens (2004), a total of four bird names were identified in which the stem -khulong 'red' (or a variant thereof) appears. These are the mocking chat rakhulong (593), three-streaked tchagra rakhulong or hubela (743), red-chested cuckoo morakhulong (377) and Burchell's coucal rakhulong (389). ${ }^{5}$ These birds are all different with regard to size, habitat and overall colouring; however, they all share one feature, i.e. a very distinct reddishbrown element, which is diagnostic in identifying the bird. In Sinclair, Hockey and Tarboton (1997) the description of the red-chested cuckoo reads as follows: 'When seen, the chestnut brown breast is diagnostic'. The mocking chat is described as having a bright chestnut-coloured underside, anal area and rump. Being diagnostic in the identification of the bird is possibly the reason why this particular colour is 
metaphorically transferred to describing cattle being of a reddish-brown colour. The notion of a particular colour being diagnostic may be the reason for the dissent among scholars with regard to the specific pattern in which the red and white colours appear on an animal; it could be that the pattern is not so much the issue, but rather the diagnostic value of the reddish-brown colour.

When in flight, the distinct white and black colours of the wings of the bateleur (146) kgwadi/kgwadira are most conspicuous, thus motivating the use of the term -kgwadi to describe a cow with distinct black and white markings.

Finally, in the Tlokwa dialect, the common fiscal shrike (732) is called thomo. This bird is characterised by a black head and back, with a distinct v-shaped white stripe on the sides. It is therefore understandable that the term -thomo would be used to refer to animals which are black with white on the body.

Apart from the association between birds and names of cattle colours, there is also a link between everyday objects which form part of the (traditional) experiential world of the Northern Sotho speaker. One such an object is phiswana 'small beer pot', which is found as the colour term -phi(t)swana 'dark brown'. Traditionally, beer pots were made from clay and baked in a kiln, resulting in a vessel of a dark brown colour. A second example, which corresponds with a similar example in Zulu, is -hlaba, which seems to refer to an unevenly coloured, somewhat spotted reddish brown animal. This term corresponds to the noun mohlaba, which refers to sand or sandy soil, and has a second sense, 'malt'. In the last instance, the colour pattern term -thamaga 'red and white, possibly spotted' could be traced back to mothamagana 'traditional beer'. This beer is brewed from sorghum, and has a light reddish-brown colour, with the solid matter giving it a spotted appearance. However, the visual link in this case seems somewhat obscured.

Lastly, the colour term -putswa 'grey' is homophonous to the noun putswa 'gray head, gray-haired old man'. This colour term seems to refer to a typical salt-andpepper pattern associated with grey hair of elderly people.

Poland-Oosthuizen (1996: 345) indicates that these metaphorical links between colour and colour pattern terms seem to be fading from the indigenous knowledge of the Zulu. She mentions that during fieldwork she found that herdsmen often knew the term for a particular colour pattern, but seemed oblivious of the relationship between the pattern and a bird, animal or tree. Whether this is also the case with regard to Northern Sotho can only be ascertained by means of fieldwork. 


\section{Conclusion}

The lexicon which is traditionally believed to contain colour terms and colour pattern terms restricted to the description of cattle is the focus of this article. An inventory of these terms was presented, illustrating the divergent views of scholars regarding the semantic content of these terms. The unique morphological features of the members of this lexicon were consequently described, followed by a corpus-based investigation regarding possible metaphoric extension of Lexicon B terms. On the one hand, it was found that this lexicon does indeed represent a system of indigenous knowledge which is in a process of attrition, due to extra-linguistic factors. On the other hand, an element of dynamism still persists, as can be seen in the metaphoric extension of these terms to the description of other objects, thus disproving the conception that these terms are restricted to the description of objects other than cattle. This process of extension was found to be synchronic, creative and somewhat idiosyncratic. On a different level, a distinct metaphoric relationship was found to exist between everyday objects and phenomena, and a number of cattle colour terms. Here, the visual link resulted in a linguistic one in the form of morphological (and phonological) similarities between colour terms and the names of these other objects.

The last word has, however, not been spoken on these terms-one aspect which still needs in-depth research is their semantic content.

Lastly, being corpus-based, this investigation has once more illustrated the value of having access to a large body of data, even when the linguistic phenomenon being studied has a relatively low frequency of occurrence.

\section{Notes}

1 This article is the result of a joint research project, undertaken with the late Prof LJ Louwrens. His untimely death prevented the final completion of the project. Even so, some of the insights reported on in this article are his, and are thus duly recognised as such.

2 The PSC is a dynamic corpus; the version used for this research contains 7.4 million tokens. It is a raw corpus, i.e. not annotated for any feature such as part of speech.

3 The information in this source is provided in Northern Sotho and has been translated into English by the author.

4 The information in this dictionary is provided in Afrikaans and has been translated into English by the author. 
5 The numbers in brackets refer to the Roberts numbers as published in Roberts Birds of Southern Africa (Ryan et al., 2005).

\section{References}

Berlin B, Kay P. 1969. Basic colour terms. Berkeley: University of California Press.

Coote J. 2012. Marvels of everyday vision. The anthropology of aesthetics and the cattlekeeping Nilotes. In: Dudley SH (ed.), Museum objects: Experiencing the properties of things. Oxford: Routledge. 245-273

Evans-Pritchard EE. 1940. The Nuer. Oxford: Clarendon Press.

Güldemann T. 1999. Head-initial meets head-final: nominal suffixes in Eastern and Southern Bantu from a historical perspective. Studies in African Linguistics 28(1): 49-91.

Kriel TJ, Van Wyk EB. 1989. Pukuntšu Woordeboek. Pretoria: JL van Schaik.

Louw JA. 1975. The nomenclature of cattle in the South-Eastern Bantu languages. Communications of the University of South Africa. Pretoria: UNISA.

Louwrens LJ. 2004. On the generic nature of common Northern Sotho bird names: a probe into the cognitive systematization of indigenous knowledge. South African Journal of African Languages 24(2): 95-117.

Maho J. 1999. A comparative study of Bantu noun classes. Göteborg: Acta Universitatis Gothuburgensis.

Mönnig HO. 1978. The Pedi. Pretoria: J L van Schaik.

Nokaneng MB, Louwrens LJ. 1988. Segagešo Mphato 9. Pretoria: Via Afrika.

Poland-Oosthuizen M. 1996. Uchibidolo: The abundant herds. A descriptive study of the Sanga-Nguni cattle of the Zulu people with special reference to colour pattern terminology and naming practice. Unpublished doctoral thesis, University of Natal, South Africa.

Sinclair I, Hockey P, Tarboton W. 1997. SASOL Voëls van Suider-Afrika. Cape Town: Struik Publishers.

Ryan P, Dean R, Hockey P (eds). 2005. Roberts Birds of Southern Africa. Johannesburg: Jacana Media.

Ziervogel D, Mokgokong PC. 1975. Pukuntšu ye kgolo ya Sesotho sa Leboa/Groot NoordSothowoordeboek/Comprehensive Northern Sotho dictionary. Pretoria: JL van Schaik/UNISA. 